\title{
Lewa Was Mama (Beloved Guardian Mother)
}

\author{
Michelle Nayahamui Rooney \\ The Australian National University
}

Mi raun lo Sir John Guise stadium

Baim buai na stori tsol

Susa wokabout i kam pulim buai lo han blo mi. Mitupla lap na tok pilai

Tsol em bingim han blo mi na tok lo iau blo mi

Susa yu raun we? Lapun mama ya i painim yu

Mi bekim - buai spakim mi tu

Susa mi stap. Raun tasol. Painim wok. Mekim wok

Kisim ol pikinini go lo skul. Yu save pinis
I was at Sir John Guise stadium

Buy betel nut and chat along

Sister approaches. From my hand she takes my betel nut. We laugh and tell a joke

She squeeze my hand and whispers in my ear

Sister where have you been? Old mother there she looks for you

I respond - giddy with betel nut

Sister I am here. Spin around. Look for work. Make work

Take children to the school. You know the usual 
Yu tok Lapun mama ya la tok wanem?

Susa em harim osem wanpla rong i painim yu

Mi bekim, ai raun blo buai wok lo isi nau

Ah yu tok. Em harim se wanpla rong $i$ kisim mi?

Ah em harim osem. Yu stap yu traim ringim em $n$ sekim em

Sekim em na painim aut wanem rong em harim

Aiyo buai kik ya tanim ai blo mi na bel blo mi sut

Wanem rong nau ya lapun mama ya $i$ painim mi?

Mi raun lo Boroko, mi sekim ol kolos lo Yakaplin

Ol kolos ya stail tumas. Sapos mi traim ating by lewa ya kalap kalap

Lewa ya tu sa taitim masol tumas. Liklik wara na ai sa raun.

Liklik wara na kros na jeles pasin sa pundaun. Ating mi stailim mi tumas

Ol kolos tu ya nais tumas. Fifti toea, wan kina na tu kina

Ai sore ating mi gat fiftin kina ba mi autim displa retpla blaus

Tasol tingting kisim masol lewa ya. Nogut em belhat nating ken

Mi raun i go i kam. Mi tingim lapun mama ya.
You say old mother there what talk she wants me for?

Sister she hears that something bad you came across

I respond, betel nut dizziness now easing up

Ah say what - she heard something bad I came across?

Ah she heard. You should try and ring and check on her

Check and find exactly what bad she heard about

Aye betel nut dizziness comes strong and heart it skips a beat

What wrong - what bad that old mother she look for me?

I go to Boroko. I check dress at market Yakaplin

Those stylish clothes. If I try - excited might my lover be

Lover too much flexing muscle. Small water and dizzy he becomes

Small water and upon me anger and jealousy come. Maybe too much styles - me

Oh those dresses very nice. Fifty toea, one kina and two kina

Aye if only I had fifteen kina that bright red blouse would be mine But muscle lover comes to mind. Anger he might feel again I go and I come. I think of that old mother there 
Maski mi traim sekim em.

Pinga paitim namba lo mobail pon

Bip bip bip bip bip bip bip bip

Putim pon lo iau na harim.

Nek blo em ba kam o?

Putim pon lo iau

Halo. Halo. Yu husait? Halo. Halo

Mi no harim yu. Yu wet. Ok ok em nau

Yu husait ya mi tok! Yu husait ya mi tok!

Maski giamanim mi mi no yangpla meri. Yu harim? Mi lapun meri ya

Mi bekim. Mi bekim. Ol kolos kala raunim ai blo mi

Ol koins lo bilum pairap tu

Halo. Lapun mama? Em mi tasol ya

Susa ya em tok yu painim mi? Aiyo sori tru mi no ringim yu

Em yu ah? Pikinini lewa blo mi. em yu ah?

Lapun mama ya em luksave lo nek blo mi

Ai yu em pikinini blo mi. Yu orait?

Ayee lewa pikinini blo mi long taim mi no lukim yu
Never mind. I try and check on

her. Fingers hit the numbers on the mobile phone

Bip bip bip bip bip bip bip bip

Put phone on the ear. Listen.

Will her voice come?

Put the phone on my ear

Hello. Hello. Who are you? Hello. Hello

I cannot hear you. You wait. Ok ok now is good

Who are you I say?! Who are you I say?!

Don't lie to me. I am not a pretty lass.

You hear? I am an old lady

I respond. I respond. Dizzy from the colourful dresses

The coins in my bilum clink as well

Hello. Old mother? It is only me.

Sister said you look for me? Aye sorry did not ring you sooner

Is that you? My beloved child.

Is that you?

Old mother there she heard and recognised my voice

Aye! You are my child. Are you ok?

Aye my beloved child very long time no see 
Mi harim em. Ol kolos kala ya tu ya

Ret, yello, grin, blu, kala kala stret na nais

Spet blo buai tu ya karamapim sait Sumuk blo paia na mit em mekim bel karai

Ah. Mama em mi tasol ya. Susa tok yu painim mi?

Yu tok. Wanpla samting yu laikim mi mekim?

Yu sik mama yu laik mi kukim sup na kam?

Yu wet bai mi go maket Malaoro painim pis na kumu mi kam kuk

Ai lewa pikinini mi painim yu steret

Ai taim mama tok olsem, lewa blo mi i sut

Wanpla rong bai em autim. Em wanem rong steret?

Ol kolos kala sun i kukim nau.

Tingting blo mi i go lo buai ken

Ai lewa pikinini blo mi. nek blo mama i wari nau

Mi harim osem masol lewa ya i mekim sampla rabis pasin

Mi harim osem em kisim wanpla meriken

Mi harim osem ai blo yu bilak yu putim ai galas $i$ go lo wok
I heard her. Those dress colours blinding me

Red. Yellow. Blue. Colours. Colours bold and nice

Betel spittle covering the side

Fire, smoke and meat - smells make my stomach growl

Ah. Mother it is only me. Sister there said you looked for me?

You say. Is there something

I can do?

Are you sik mama? Shall I cook some soup?

You wait let me find fish, vegies at market Malaoro. I'll come cook.

Aye beloved child I searched for you I did

Aye when mama said like that my heart it skipped a beat

What's this wrong she will reveal? What's this bad she talks about?

Those dresses sun scorched now. Betel nut kick comes to mind

Aye beloved child of mine. Mama's voice is worried now

I hear that muscle lover there he does some bad bad things

I hear he's has got another mistress now

I hear that your eye is black. That you wore dark glasses into work 
O tok tru yu harim lapun mama

Tasol yu save pinis em pasin maret mipla stap

Em orait. Em go wok. Haste nait mipla go raun lo tambu meri ya Ol pikinini orait mipla stap tasol

Ai na mi kam raun ai giris long kolos lo Yakaplin

Lapun mama em maret pasin tasol - mi orait

Na yu stap tasol yu no sik? Aiyo mi stap pinis mi kam raun painim pis

Tasol lapun mama ya iau blong em i no harim

Olgeta gutpla toktok blo mi swit tumas

Em $i$ no harim osem mi tok em maret pasin tasol

Het storong ya lapun mama ya em i tok

Lewa pikinini blo mi

Wari kiliim mi turu mi tingim yu

Mi tingim yu bai mi halpim yu olsem wanem?

Maret pasin em turu tasol skin blo yu em skin blo mi
Ok. Old mother dear all that you hear is true

But you know these ways are marriage ways. We are here

It's ok. He's gone to work. Last night we visited the sister in law

The children are alright. We are ok

Aye and here I am admiring clothes at Yakaplin

Old mama it's just marriage ways that is all. I'm ok

And you ok? You are not sick?

Aye I'll make sure I'll find fish I'll come

But old mother there her deaf ears did not hear

All my good talk, my sweet sweet words

She did not hear me say that this is marriage ways that's all

That stubborn mother there she continued to say

Beloved child of mine

When I think of you I am worried sick

I think of helping you. How - how can I help?

Marriage ways that's true but your skin is my skin 
Pikinini yu harim mi.

Yu harim gut

Sampla toktok blo mi yu kisim nau

Yu harim mi gat sampla samting.

Samting ya em pawa stret

Samting ya em masol lewa bai silek.

Yu harim? Yu klia lo tok blo mi?

Ai lapun mama yu mekim bikpla tok

Em pawa ya em wanem samting stret?

$\mathrm{Na}$ i stap we? Yu bai givim or bai mi baim?

Em lo maket or lo balus?

Ai pikinini. Yu noken wari.

Yu em lewa blo mi stret.

Mi wari lo yu na mi painim

Em mi yet bai mi givim

Noken tingting noken wari noken pret

Lapun mama na displa pawa ya displa malera

Em i wel, o sop, or lip or simuk, o paura or wara?

Em Kawar? Mi no save lukim yet

Plis yu tok klia na mi harim
My child listen to me.

Listen very carefully

My words right now you take

You listen. I have something.

This thing is powerful true

This thing. Your beloved muscle

will calm down. You hear?

You understand?

Aye old mother what you say is very deep

What is this power thing you talk about?

Where is it? Will you give it? Will I buy?

Is it at the market or imported?

Aye child. Do not worry. You are my beloved child

I worry for you I found this thing.

This thing I will give to you

Don't think. Don't worry.

Don't fear.

Old mother - and this power this magic

Is it oil, or soap, or leaves, or smoke, or powder or water?

Is it ginger? I have not seen it yet.

Please explain so I can hear 
Lewa pikinini em wel yu putim lo skin blo yu

Lewa pikinini em ti yu tanim bai masol lewa i diring

Lewa pikini laik blo yu tasol

Yu tokim mi lo laik blo yu na mi givim

Ai lapun mama. Ai lapun mama

Nau em maus blo mi em pas na ai blo mi em op

Tingting nau i go bek buai.

Mi spetim buai ating bai tingting gut i kisim mi

Trangu lapun mama wari lo mi

Trangu lapun mama tingim mi

Em painim wei lo halpim mi lo taim nongut blo mi

Het blo mi i raun lo kainkain planti tingting

Mi tingim laip, mi tingim maret pasin tu ya

Em sa swit na olgeta samting em orait

Tasol taim masol lewa ya sa apim wara

Na han skin sa tait na han sa slek

Aiyo maret pasin ya tu sa hat

Skin sa pen na maus sa buruk

Lewa sa pen na kainkain wari tingting sa kamap

Aiyo maret em orait tasol masol lewa sa tanim baksait
Beloved child. It's oil you smooth on your skin

Beloved child it's tea you make. Your beloved muscle he will drink Beloved child it's up to you

Tell me if this is what you want and I will give

Aye old mama. Aye old mama

Now my mouth is silent but my eyes open wide

Betel nut comes back to mind

Maybe betel nut will bring clarity back to stay with me

Poor old mama worries about me Poor old mama she thinks of me She finds a way to help me out when bad times come to me

My head spins with all kinds of thoughts

I think of life, I think of marriage ways as well

It is very sweet and everything is alright

But when beloved muscle lifts his water

And with his flexed up arms and his hand he takes a strike

Aiyo marriage ways they can be hard Skin will hurt and mouth will break Heart aches and all kinds of worry thoughts come up

Aiyo marriage is ok but beloved muscle he can turn his back 
Mama lewa yu tok ken ah

Dispela samting wanem pawa stret?

Bai mi plai lo nait? Bai mi lukim

wanem?

Nogut masol lewa lukim mi?

Pikinini lewa yu sa wari nating stret

Em i no wanpla samting nogut

Ai mi tokim yu. Em winim wel

blo Kutubu. Yu rabim wel lo skin blo yu

Yu tanim ti na em bai dring em winim ti blo Kurumul

Aiyo pikinini lewa bai olgeta wari i pinis

Bai masol lewa blo yu bai masol slek

Em bai lukim yu bai lukim yangpla flawa

Em bai lukim swit swit flawa susu $i$ sanap

Aiyo pikinini lewa, masol lewa bai no nap

Tromoi ai i go lo narapla meri ken

Yu tasol yu bai flawa sanap stap

Wanem kainkain tingting em i gat lo narapla

Em bai lus tingting.

Masol nau sa tait lo brukim maus blo yu

Masol ya bai slek na silip lukautim yu

Pikinini lewa olgeta wari blo yu bai ol go tu
Beloved mama please say it again

This thing what power is it?

Will I fly at night? What will I see?

Maybe muscle lover will see me?

Beloved child you worry over nothing

It is nothing bad

Aye I tell you. It's better than the oil of Kutubu. You smooth this oil on your skin

You boil a tea and he will drink its better than tea of Kurumul

Aiyo beloved child all your worries will be no more

Your beloved muscle his muscles will ease up

He will only see a young flower that is you

He will see a sweet sweet flower.

Breasts young and tender

Aiyo beloved child muscle lover he will not

Cast his eyes on another woman

Only you. A flower you will stand

All his many thoughts of another

He will cast away

Those muscles now intent on hurting you. Break your mouth

Muscles will relax and lie down to care for you

My beloved child all your worries disappear 
Yu putim wel lo skin o tanim ti em dring

Tupla wantaim wankain tasol

Olgeta wari blo yu bai pinis

Olgeta kainkain tingting em sa gat lo paul bai lus

Mi tokim yu em pawa stret, malera, posin,

Mi tokim yu olgeta wari blo yu bai ronowei

Mi holim stap sapos yu laik kam lukim

Mi haitim wanpla tasol stap nogut yu tok mi karim kam

Aiyo olgeta skin blo mi kirap

Aiyo kainkain tingting raun lo het

Ating buai nau em bai stretim displa het

Lapun mama ya i tromoi toktok stret

Ok lapun mama bai mi pinisim raun na mi kam

Yu stap lo we? Bai mi painim yu Yu wetim Tunde nambaut mi bai kam Yu harim? Displa em mi harim em $i$ swit tumas
You smooth this oil on skin or make tea he drinks

Both are very similar

All your worries they will disappear All his thoughts of going around he will forget

I tell you it is powerful, Magic, Potion,

I tell you all your worries they will run away

I hold it here in case you want to see

I keep one only in case you want I can bring to you

Aiyo goosebumps ripple through my skin

Aiyo all kinds of thoughts enter my head

I think betel nut now will straighten this here head

This old mother she her talk is making sense

Ok old mother let me finish

I will come

Where are you? I will look for you. I'll come around Tuesday. You wait. You hear? This thing I hear it sounds so very sweet 
Mi stap mi stap na salim

planti tingting go

Olgeta tok blo lapun mama em orait

Tasol nau lo pepa kainkain stori sa kamap

Olsem malera na posin em i no gutpla pasin

Ol tok ol Hagen kilim wanpla mama

Ol Hagen kukim mama ya lo paia

Olgeta man meri sanap na lukim em

Ol tok pawa, malera, posin mama ya em strong tumas

Poret blo ol ol kilim em ol Hagen ya

Ol tok ol wansol Bougainville kilim tripla meri

Ol susa ya ol mekim rong? Ol mekim wanem rong turu?

Na lapun mama ya em painim wei lo halpim mi

Lapun mama ya em toktok gut tasol

I no gat wanpla rong. Em painim sol wei lo halpim mi

Em wari kilim em lo mi na em $i$ painim mi

Ai planti kainkain tingting mi salim
I stay. I stay and dwell a lot on this

All her words are ok - old mother

But now many many stories show up in the papers

That magic and poison are not good ways

They said the Hageners killed a woman

The Hageners burnt her on a fire

All the men and women stood and looked at her

They said her power, her magic, her poison was too strong

Their fear overcame them those Hageners

They said the islanders on Bougainville three women they did kill

Did those sisters do a wrong? What wrong exactly did they do?

And old mother there she has found oil to help me out

Old mother there her words are very good

There is nothing wrong at all. She just found way to help me out

She is worried sick for me and all she did is look for me

Aye all kinds of thoughts I dwell upon 
Tunde kam na Tunde go na mi no go

Painim lapun mama ya. Mi no go

Friday kam na masol lewa apim wara

Ai taim nogut blo mi i kam han buruk

Han buruk mi go hausik go painim marasin

Ol nes $i$ sasim mi lo baim han buruk

Ol tok mi rong lo man

$i$ paitim $m i$

Ai masol lewa em kam lukautim mi klostu tripla wik

Narapla Tunde kam na go. Narapla potnait kam

Wara i kapsait olsem tais. Masol lewa ya apim wara gut

Em maret pasin tasol mi tok.

Olgeta samting $i$ orait

Maret pasin tu ya mi tok. Taim nogut taim wara ron mi sa kisim taim

Mi tingim ol gapman nau ol tok lo rausim pasin kilim galas meri

Mi tingim taim lapun man i sik na

Blut blo pisin ol glasim wok painim aut

Husat turu em i bagarapim em. Wanem has blo sik blem
Tuesday came and Tuesday went.

I did not go

Look for old mother there. I did not go

Friday came and muscle lover his drink he lifted

Aye when bad times come. Broken arm

Broken arm to hospital I go. Look for medicine

The nurses charge me for my broken arm

They say it's my fault - the man he fights with me

Aye nearly three weeks muscle lover there he looked after me.

Another Tuesday comes and goes. Another fortnight comes.

Water pours like a flood. Muscle lover lifts his water well

Its only marriage ways I say.

Everything will be ok

But marriage ways I say. When bad times come and water runs suffering I stay

I think of government now they say to get rid of sorcery killings I think of my old man - sick The blood of a bird they used to diagnose

Who to blame for making him sick. What to blame for making him sick. 
Mi tingim taim lapun man i dai na rokrok kam sindaun

Lo dua lo haus em makim taim nogut

Mi tingim diriman. Mi tingim sain blo tumbuna

Ai lapun mama ya em i no rong. Em wok lo wari tsol lo mi

Mi tingim mama karim i stori lo wanpla lapun papa blem

Em tokim em lo bai ol $i$ wasim em

Mama karim bekim. Ai papa yu no harim yet?

Ol lotu lain i wasim mi lo wara na Jisas em was man blo mi nau

Na bubu man ya bekim em olsem

Pikinini em orait mi ting Jisas em i gutpla man

Was man blo ples antap. Tasol yu save samting blong graun em i pawa tu

Olsem na bai mipla wasim yu

Na trangu mama karim daunim em yet nau

Na larim lapun papa wasim em na spetim em lo buai

Kisim strong blong tumbuna na Papa Got wantem

Em displa pasin tumbuna bin stap lo taim bipo na nau i stap lo blut
I remember when my old man died and the frog came and sat

On the door of the house to tell us bad news coming

I think of dreams I had. I think of signs of ancestors

Aye old mother there she is not wrong. She is only worried for me

I think of birth mother's story of her old father in the days

He said to her that they must wash her too

Birth mother responded. Hey old man have you not heard?

The churchfolk washed me and Jesus he is my guardian watchman now

And Grandfather he responded like this

Child that's all right I think Jesus is a good man

He will watch you from above. But as you know the spirits of the land are powerful

That is why we must anointment will protect you too

So poor dear birth mama. She humbled herself now She let the old man wash her. Protect her and anoint her with betel nut spittle Taking strength from ancestors and Father God as well

These ancestral ways have been here before and now they're in the blood 
Na masol lewa ya masol i no slek

Masol lewa ya i taitim han olgeta taim

Na skin blo mi laik dai. Mi sa pundaun olsem lang

Skin blo mi i les na wari kilim mi

Ol poroman blong masol lewa tu ya Ol $i$ tokim em olsem. Em ya kaikai kawar na spetim meri ya

bai em i lusim yu. Rausim em.

Maus blong em i sap tumas. I gat planti resa mama stap

Mi traim lapun mama ya mi traim em tasol

Pinga blo mi paitim pon

Bip bip bip bip bip bip bip bip

Lewa blo mi sut. Mi pulim win

Tasol nogat susa meri ya em tromoi inglis kam

'The person you are calling is not available. Please try again later' Aiyo lapun mama ya yu go we? Yu stap o?

Em orait bai mi traim gen bihain

Narapla Tunde kam na go Bip bip bip bip bip bip bip bip

Susa meri tsol em bekim kam ... Em orait bai mi 'try again later' Bip bip bip bip bip bip bip bip
And muscle lover. Muscle did not slack Muscle lover he always flex his arms And my skin. It is numb. I fall down like a fly

My body is tired and I am worried sick.

And the friends of muscle lover too To him they said like this. Here, eat this ginger and curse that woman She will leave you. Get rid of her, Her mouth is way too sharp. There are many other beauties here

Let me try old mother there. Let me just try her and see My fingers hit the phone Bip bip bip bip bip bip bip bip My heart it skips a beat. I take a breath

But it's only sister on the phone in English she responds

'The person you are calling is not available. Please try again later'

Aiyo old mother dear where are you? Are you there?

That's ok I will try again later

Another Tuesday comes and goes

Bip bip bip bip bip bip bip bip

Only sister responds again ... That's alright I will try again later

Bip bip bip bip bip bip bip bip 
Tripla mun i lus na les lo wet mi ketsim bas i go

Go kamap lo ples we op kat timba haus sanap. Lapun mama. Yu stap?

Trangu taim mi go kamap i nogat haus $i$ stap. Sit blo paia tsol i bilasim graun Aweee mi sakim het. Na op kat haus? I bin sanap lo bia

Isi tasol mi askim ol lain lo sait sait haus

Ay plis yupla lukim lapun mama ya? Em go raun?

Ssss weeesshh susa meri yu husat? Yu lewa pikinini?

Sori tru lapun mama go pinis

Mipla kisim kainkain tingting na bel hevi

Lapun mama ya em pawa meri stret na bilum i pulap

Malera, kambang, posin, kawar glass meri em em stret

Olgeta pawa ya em holim stap na pawa blem i winim mipela

Poret em kisim mipla taim harim kainkain masalai

Na pisin krai lo nait. Ol meri Samarai palai lo bik moning

Rokrok singaut na binatang $i$ dai lo winduo

Mipla kisim taim lo kainkain birua tingting
Three months go by and sick of waiting I catch a bus and go

I arrive at the place where the off cut timber house stands. Mama are you there?

Alas when I arrive there is no house but ashes decorate the ground Aweee I shake my head. Off cut house? It used to stand right here

Whispering I asked the neighbours nearby

Aye please have you seen this old mama here? Has she gone out?

Shhh weeeeshh sister girl who are you? Are you beloved child? Sorry true but old mother she has gone

We were faced with all sorts of thoughts and worries too

That old mother she was very powerful. Her bag was full of stuff

Magic. Lime. Poison. Ginger.

Sorceress she was that is true

All the powers that she had they overcame us you see

We were filled with fear when we heard all sorts of spirits

And birds they call at night. Samarai women they fly over near dawn

Frogs they call and bees drop dead on the window sill

We were faced with all sorts of thoughts and worries too 
Olsem na ol man i makim maus blo mipla ol it tok

Ol $i$ tok. Em mas go! Em i mas go na ples bai orait ken!

Susa lewa mipla kukim haus blo em olsem na sit blo paia yu lukim

Trangu kilim em nogat tasol ronim em mipla sutim ston

Ayee nau em bikpla wari tingting kisim mi

Em go we? Mi askim ol. Em orait? Mi askim ol

Em mama lewa blo mi stret na yupla ronim em

Wai na tripla mun i lus mi wet na painim pis?

Ol gutpla lain ol tokim mi

Susa noken pret lapun mama mipla harim

Lapun mama go painim pemili lo Morata

Em no dai tasol hia em noken kam bek no gut bel hat pasin i kamap

Ayee gutpla tingting $i$ kisim mi

Em $i$ no dai. Em i ronowei go Morata

Em orait bip bip bip bip bip bip bip bip

Susa meri tasol bekim Inglis kam ... 'try again later'
So the men who represent.

The men they said

They said. She must go! She must go and our place will be safe again!

Beloved sister so we burnt her house.

That's the ashes that you see.

Poor thing. Kill her we did not. But chase her we did and we did so throwing stones

Ayee I am overcome now with concern for her

Where did she go? I ask of them. Is she ok? I asked of them

She is my beloved mother how could you chase her so

Why did I wait three months? Find fish and come to her.

Some good folks they told me this

Sister have no fear. Old mother there we have heard

Old mother has gone to family at Morata

She did not die but here she must not return. In case angry ways arise

Ayee now my thoughts are calmer now

She did not die. She has runaway to Morata

That's ok. Bip bip bip bip bip bip bip bip

Sister lady only English she responds ... 'try again later' 
Tunde kam na Tunde go narapla tripla mun i lus

Bip bip bip bip bip bip bip bip

Aiyo mama lewa mi salim tingting kam

Wai na mi no harim tok blo yu

Maret pasin em tasol $i$ no wanpla samting tu

Maret pasin em tasol. Masol lewa apim wara

Masol lewa paitim mi, skin i pen, blut $i$ kapsait

Masol lewa kisim narapla, na narapla na narapla meri ken

Ating sapos mi harim yu - was mama lewa, lapun mama

Ating sapos mi harim yu masol lewa ya bai dai lo mi tasol

Ating bai maret pasin stap orait

Ating bai pemili tu bai sindaun gut

Em orait na nau mi salim tingting tsol

Mi bai bip bip bip bip bip bip bip bip

Inap swit nek blo yu pairap lo pon lewa was mama blo mi

Diriman na wetim wanpla gutpla taim bai masol lewa ya i dai lo mi tasol.
Tuesday comes and Tuesday goes.

Another three more months pass by

Bip bip bip bip bip bip bip bip

Aiyo beloved mother my thoughts

I send to you

Why did I not heed your counsel

It's only marriage ways. It's really no big deal

Only marriage ways. Muscle lover takes his drink

Muscle lover beats me up. Body

hurts. Blood - it pours down

Muscle lover takes another and another and another woman again

Perhaps if I had taken heed - guardian beloved mother. Old mother

Perhaps if I had taken heed. Muscle lover - in love with me alone

Maybe marriage life would be alright Maybe family life would be ok

That's ok. So now I think of you and ponder these

I will bip bip bip bip bip bip bip bip Until I hear your sweet voice on the phone. My beloved guardian mother

Dream and stay and wait for one fine day when muscle lover would die for me alone. 


\section{Afterword for Lewa Was Mama}

Lewa Was Mama-Beloved Guardian Mother-can be considered an ethnographic poem (Denzin 1997; Maynard and Cahnmann-Taylor 2010). It is reflexive auto-ethnography (Ellis, Adams and Bochner 2011; Reed-Danahay 2001) and in this afterword I elaborate its context and relation to the themes of this collection. The poem is set in Port Moresby, the capital city of Papua New Guinea (PNG), where I was born and lived for many years. It draws on decades of life stories and experiences, including those from fieldwork for my $\mathrm{PhD}$, which was conducted over a six-month period from January to June 2013. I wrote the poem-or perhaps more truthfully, the poem came to me-after returning from my fieldwork. As I started to sift through my data, I found myself struggling to reconcile gaps between the big picture development narratives about women's empowerment and the intimate details of the day-to-day lives of the many women I knew.

The starting place for the poem is the Sir John Guise Stadium, a key feature of the city's landscape and the site of many national celebrations, such as Independence Day, sports and an important national campaign calling for action on violence against women. For many years it also played a part in my family's daily routine. Watching soccer training and games, walking around the stadium for exercise, and catching up with family or friends meant hanging around the informal markets in and around the stadium.

The poem's narrator, a woman who resides in the city, leads the reader from the stadium on some of her typical outings around the city as she reasons through her own dilemmas in love and marriage (similar to those discussed by Ceridwen Spark and Jenny Munro in this volume). She must contend with the dilemma she faces when offered help to deal with her marital problems by her elderly friend-Lewa Was Mama - who lives in a Moresby settlement. Boroko is a residential suburb. Morata is a suburb into which merges one of the city's larger and older informal settlements. Malaoro is one of the larger fresh food markets and Yakaplin is one of the largest used clothing markets in the city. Kutubu is the site of one of PNG's oil projects located in the highlands region at Lake Kutubu. Kurumul tea comes from the Kurumul tea plantation, also located in the highlands region of PNG. 
The poem is set in 2013 when PNG and various international agencies were grappling to understand and find solutions to the epidemic of violence in PNG, which includes sorcery and domestic violence.

\section{Sorcery and gendered violence: A humanitarian crisis}

Just months before I commenced my fieldwork in 2013, the nongovernment organisation (NGO) Doctors Without Borders (Médecins Sans Frontières, MSF) declared the prevalence of sexual and domestic gendered violence in PNG to be a humanitarian crisis. Sadly, 2013 turned out to be a significant year for the narrative of violence in PNG's history. In February, shockwaves were felt through the international community as news and graphic images emerged of Kepari Leniata, a 20-year-old woman in Mt Hagen. Leniata had been set alight after she was accused of sorcery and burnt to death in broad daylight in front of hundreds of onlookers. In April, the world learned that in Bougainville four women had been abducted after being accused of practising sorcery. One-Helen Rumbali-was beheaded and the other three held captive for several weeks. A foreign national was gang raped in Madang around this time.

\section{National responses}

In many ways, these events led to an awakening in PNG of the need to address violence. As part of this, a movement to hold a national Haus Krai to acknowledge the crisis of gendered violence in PNG emerged. Haus Krai is the Tok Pisin term for a house or site of mourning, where people gather to mourn a deceased person. As the movement gained momentum, a number of Haus Krai events were held throughout the world to express solidarity with the victims of violence and to call for action to address violence in PNG.

In Port Moresby the national Haus Krai was held at the Sir John Guise stadium. I was conducting fieldwork while following these events and in May 2013, attended the national Haus Krai in the city. 


\section{The space between national and international responses and lived experiences}

After fieldwork my evenings would involve catching up on personal and mainstream news via Facebook. As there was no television where we were living, Facebook was an important way for me to keep abreast of the Haus Krai movement. Despite being a 15-minute drive from the Sir John Guise stadium where people were gathered, I noticed a difference between the lived reality of my life and that of the people with whom I was interacting in the field. Many people in the settlement community had phones but because of a lack of electricity they generally were off because the batteries were flat or to preserve them for the most important calls. People asked if I had brought newspapers with me as a way to catch up on the news, but also to add to their stocks of toilet paper used in the pit toilets. A few houses had TVs and there were a few communal TVs, but most people seemed unaware of the national Haus Krai movement.

Yet violence was intimately interwoven in the day-to-day stories of struggle and survival (see Jolly 2012; Jolly, Stewart with Brewer (eds) 2012): a woman slashed with a knife by her brother-in-law; a woman beaten; a family chased from their home because one of its members was accused of sorcery; stories of love and magic to help allay a man's violent tendencies or tame his indiscretions; women elders caring for their grandchildren in the absence of parents; an elderly grandmother caring for her orphaned grandchildren after their parents had died of AIDS; and community leaders striving to address development needs while battling in courts to stay forceful evictions.

\section{Celebrating indigenous spirituality: Sisterhood and motherhood}

In my life, a dream or the sighting of a specific animal or other 'sign' conveys a meaning and is usually reflected upon to anticipate the future or explain the past. Traditional legends of women, love, seduction, magic, sorcery, weaving, gardening and life also resonate in my memory. The lived realities of many women I know reflect this same rich interweaving of the spiritual and the worldly. This poem is a celebration of the indigenous spirituality—as opposed to indigenous sorcery and witchcraft. 
The space between the public responses to violence that highlight the brutality and the private narratives of witchcraft and magic relates to the more positive and spiritual magical effects that are also elements of the supernatural. As I watched the news of Leniata and Rumbali in disbelief, my emotional response involved my understandings of positive stories of spirituality. Were these phenomena one and the same thing? How had their communities judged these women so harshly when these communities placed value on their embodiment of spiritual good? By believing in my own version of spirituality was I complicit in 'practice' that so terrified communities?

Martha Macintyre noted in her work among Tubetube people that 'stories about witches and spirit beings of various sorts provide far richer material on Tubetube ideas of embodiment, social and individual morality, and personhood' that 'constitute a discourse on embodiment' (Macintyre 1995: 40). Lewa Was Mama may well be viewed as such a discourse about the embodiment of contemporary Melanesian femininity. Lewa Was Mama is the 'pivotal antinomy' (ibid.: 42). To her community, she embodies the anti-social female witch; to her young friend she offers spiritual protection, love and healing. As for the people of Tubetube (Macintyre 1995), the stories of Lewa Was Mama and her friend are interwoven with conflict and violence.

In this space between the public responses to violence and the private lives of those experiencing it lies the less discussed narrative- that of the mutual support women give each other. The poem celebrates the 'mutuality of being' (Sahlins 2014: 62) in which women are mutually constituted (ibid.) through sisterhood and motherhood. In the way the Melanesian person is relational and partible (Strathern 1988), so too the Melanesian woman in relation to herself and other women can be regarded as relational and partible. This feminine connection and support as well as the full extent of the impact of violence is often rendered invisible when women are cast as individual victims, rather than socially connected. The poem is both a celebration of bonds between women and of indigenous spirituality - in its many unfathomable forms. Reflecting back to when I wrote the poem, I privileged the feminine voice and feminine relationality even though I often criticise Western feminist discourses for not being culturally sensitive to PNG women's lived experiences, anchored in social relationships that include men. The poem explores the relationships and exchanges that women conduct among themselves in ways that acknowledge male domination and 
gender violence [and in doing so, they make possible] radical changes in gender relations, even perhaps in the models of the person' (Jolly 2012: 5; also see Macintyre 1995 for a discussion). By contrast, but similarly highlighting the ruptures in gender relations that contemporary life has produced, Stephanie Lusby's chapter (this volume) enables us to see our own complicity in perpetuating gendered violence when we ignore the intersection between producing security and male aggression.

I hope that by foregrounding feminine narratives of women's relationality and opposing the violence they experience, Lewa Was Mama enables us to see how narratives of 'women's empowerment' potentially can work to diminish the relationships that women draw on for mutual support. They can also background the broader impacts of violence on communities or networks of women who suffer collectively. The national Haus Krai movement is a public performance of this collective suffering but still speaks to the masculine state domain, to intervene and address violence perpetrated by men on women. Lewa Was Mama and her younger friend feel each other's pain as women and try to support each other through friendship and material (fish) and spiritual (magic) gifts.

In another example of changing gendered landscapes, Tait Brimacombe (this volume) discusses how the advent of mobile phones and social media platforms are providing women with avenues to participate in dialogue that would not previously have been possible. Similarly, indigenous spiritual connections also are being revolutionised by technology. In Lewa Was Mama, the two women never actually meet in person but this does not lessen the intensity of the feelings and emotional interactions between them. After the initial message conveyed at the market by their mutual friend - a sister - they communicate primarily through their mobile phones, or through the community from which Lewa Was Mama has fled. Mobile phones facilitate conversations about such issues.

\section{Transformation and intergenerational mutuality}

Lewa Was Mama shows how mutual constitution of women is also intergenerational. In embodying this spirituality, older women especially find ways of passing their knowledge on to younger generations. This shapes gender and transformation in the Pacific. 
When I ask my birth mother about her early years in the 1940s, she describes them simply. She was born in a small hamlet called N'Drayongai in the Lahan area of Bulihan village on Manus Island. At birth she was wrapped in traditional bark cloth, n'drih. As a girl she slept in a hessian bag that had been used for copra. Her mother suffered from leprosy and was sent to far off New Ireland for treatment. She never saw her mother again. When the news reached her family that her mother had died, succumbed to her leprosy, her father decided to withdraw her from the new colonial school so she could care for her two younger sisters. Enthusiastic to attend school, she went on a hunger strike for several days until he relented. Frustrated and angry, her father allowed her to return to school- 'Go to school and see where it will get you!'- he scolded her. As a young woman, while away from her home, she converted to Christianity but could not resist her elders' insistence that she be 'washed' to 'protect' her from earthly spiritual forces. As a mother, she and others acknowledge the presence of loved ones passed, who gently lit up the evenings with their flickering glowthe fireflies-ensuring our lukaut (care). Her stories and those of others told to us as children, transfer their indigenous personhoods and inform our understandings and our own enactment of this spirituality even in the urban context. She-Nahau Kambuou Rooney-while helping to care for her younger sisters and remaining anchored in the family that raised her, went on to become PNG's second ever female-elected Member of Parliament in 1977 and PNG's first female cabinet minister.

The personal stories of women's cultural and social roots, including their adaptive strategies and challenges, can become obscured in the overarching development narratives around women's empowerment. Dame Carol Kidu, Julie Soso, Enny Moaitz, Dame Josephine Abaijah, Margaret Nakikus, Felecia Dobunaba, Rose Kekedo, Naomi Martin, Meg Taylor, Anne Dickson-Waiko, Orovu Sepoe, Waliyato Clowes, Nahau Kambuou Rooney and others all rose to the top in their fields (Macintyre, this volume) while navigating their own PNG sociality with the professional and international demands placed on them. Women's status in Melanesia reflects their ability to adapt to place-determined socioeconomic and political factors that shape how women are seen, factors that usually place the traditional in opposition to the modern (Soaki, this volume). These oppositions privilege men and are often amplified in the urban context (for a discussion see Soaki, this volume; Spark, this volume; Cox, this volume). 
Lewa Was Mama seeks to foreground the complexity of this spiritual and social connection between women in PNG and how it possibly plays an important part in enabling them to adapt and navigate the complex and sometimes inexplicable terrain of tradition, modernity, love, nurture, hope, joy, pain, violence and conflict. When the cameras have been turned off, the development workshops have ended and the national and international movements lose their momentum, this connection also enables them to retain a sense of self. It enables them to retain a degree of distance from universalising gender equality discourses that seem to prefer to ascribe 'success-hood' or 'victim-hood' to the singular woman. As Macintyre (this volume) states, 'Melanesian social worlds are in flux'. I hope that Lewa Was Mama makes visible some of the contributing factors and adaptive responses to this state of flux.

\section{References}

Denzin, Norman K. 1997. Interpretive Ethnography: Ethnographic Practices for the 21st Century. Thousand Oaks, London and New Delhi: Sage Publications. doi.org/10.4135/9781452243672.

Ellis, Carolyn, Tony E. Adams and Arthur P. Bochner. 2011. 'Autoethnography: An overview'. Historical Social Research 36: 273-90.

Jolly, Margaret. 2012. 'Introduction-Engendering violence in Papua New Guinea: Persons, power and perilous transformations'. In Engendering Violence in Papua New Guinea, ed. Margaret Jolly, Christine Stewart with Carolyn Brewer, pp. 1-46. Canberra: ANU E Press. Online: press.anu.edu.au/publications/engendering-violencepapua-new-guinea (accessed 12 August 2016).

Jolly, Margaret, Christine Stewart with Carolyn Brewer (eds). 2012. Engendering Violence in Papua New Guinea. Canberra: ANU E Press. Online: press.anu.edu.au/publications/engendering-violence-papuanew-guinea (accessed 12 August 2016).

Macintyre, Martha. 1995. 'Violent bodies and vicious exchanges: Personification and objectification in the Massim'. Social Analysis: The International Journal of Social and Cultural Practice 37 (April): 29-43. 
Maynard, Kent and Melisa Cahnmann-Taylor. 2010. 'Anthropology at the edge of words: Where poetry and ethnography meet'. Anthropology and Humanism 35(1): 2-19. doi.org/10.1111/j.15481409.2010.01049.x.

Reed-Danahay, Deborah. 2001. 'Autobiography, intimacy and ethnography'. In Handbook of Ethnography, ed. Paul Atkinson, Amanda Coffey, Sara Delamont, John Lofland and Lyn Lofland, pp. 407-11. London, Thousand Oaks, New Delhi: Sage Publications. doi.org/10.4135/9781848608337.n28.

Sahlins, M. 2014. What Kinship Is - And Is Not. Chicago and London: University of Chicago Press.

Strathern, Marilyn. 1988. The Gender of the Gift: Problems with Women and Problems with Society in Melanesia. Berkeley and Los Angeles, CA: University of California Press. doi.org/10.1525/ california/9780520064232.001.0001. 
This text is taken from Transformations of Gender in Melanesia, edited by Martha Macintyre and Ceridwen Spark, published 2017 by ANU Press, The Australian National University, Canberra, Australia. 